\title{
自己組織化メソポーラスシリカの形態制御と 機械的性質の評価*
}

\author{
松室昭 仁** 真田 祐 紀***高橋 裕 $^{+}$ \\ Morphological Control of Mesoporous Silica Materials with Self-organized Structure and Their Mechanical Properties
}

\author{
Akihito MATSUMURO, Yuuki SANADA and Yutaka TAKAHASHI
}

\begin{abstract}
Mesoporous silica materials with self-organized structures that consist of periodic nano-scale pores have been expected to be of great significance in realizing micro-nano systems. The morphological control of the mesostructured materials are demonstrated by varying the concentration ratios of $\mathrm{CH}_{3}\left(\mathrm{CH}_{2}\right)_{15} \mathrm{~N}\left(\mathrm{CH}_{3}\right)_{3} \mathrm{Cl}(\mathrm{C} 16 \mathrm{TMACl}) /\left(\mathrm{C}_{2} \mathrm{H}_{5} \mathrm{O}\right)_{4} \mathrm{Si}$ (TEOS) and $\mathrm{HCl}$ solution. The increase of the concentration ratios changes the shape and size of the mesostructured materials. Linear hexagonal rods, good example for this application, can be synthesized by the reaction of $7.04 \mathrm{~g} / 4.48 \mathrm{ml}$ for C16TMACl/ TEOS and $70 \mathrm{ml} / 20 \mathrm{ml}$ for $5 \mathrm{~N} \mathrm{HCl} / \mathrm{H}_{2} \mathrm{O}$. The most suitable calcination conditions for higher strength are determined by varying the calcination temperature up to $1000{ }^{\circ} \mathrm{C}$. The hardness, elastic modulus and fracture load of the mesostructured hexagonal rods are clarified by nano-indentation method.
\end{abstract}

Key words : Mesoporous silica materials, Self-organized structure, Morphological control, Mechanical properties

\section{1.はじめに}

急速な微細加工技術の進展は, 収束イオンビームや電子 ビームの利用と伴に数十 nm以下の加工1)を可能にしている.ま た, 走査型プローブ影微鏡 (SPM) を用いた加工2) では原子や分子 操作を実現しており,ナノシステムの開発に向けたトップダウ ンによる技術は確立しつつある.しかし,これらの方法は, 平 面的に単純な構造の形成には適切であるが, 3 次元的に複雑な 構造体の加工は困難である。これらの問題を解決し, ナノス ケールレベルの構造体を,自発的に形成する能力を利用する自 己組織化による加工技術が近年大きな注目を集めている.工学 的に自己組織化を用いた応用も試みられ, 例えばチオール分子 の作るセルフアセンブル膜を用いたマイクロコンタクトプリン ト ${ }^{3)}$ や, 陽極酸化アルミナが孔径 $5 \sim 450 \mathrm{~nm}$, セルサイズ 10 $500 \mathrm{~nm}$ 程度のポーラス構造を形成し,さらに自己修復能を有す る点に着目した研究例 ${ }^{4}$ などがある. その他にもDNAの選択的 結合性を用いたコンピュータなど生命現象と直結した研究5) 報告され,未来を担う新しい加工・科学技術として発展しつつ ある・

このような潮流のなか, 1989年に界面活性剤のミセルを鋳型 として, 自己組織的に周囲の親水部にシリカ壁が形成されるメ ソポーラスシリカ $(\mathrm{MCM}-41)$ が発見された.この材料は極めて規 則性の高い多孔質材料で, 界面活性剤のサイズによって自由に 制御できる直径約 $2 \sim 50 \mathrm{~nm}$ の周期配列した細孔を有し, 大き さ数〜数十 $\mu \mathrm{m}$ 程度の様々な形態を有する構造体が, 数種類の 試薬を混合後静置することで形成されることが報告された これらの構造体は特異な構造のため比表面積や比容積が大きい

\footnotetext{
* 原稿受付 平成 15 年 6 月 24 日

** 正会員 名古屋大学工学研究科 (名古屋市千種区不老町)

*** 名古屋大学大学院 (名古屋市千種区不老町)

$\dagger$ 三重大学工学部（津市上浜町）
}

ばかりでなく,シリカ材に起因した耐熱性および水熱安定性に 優れる.それゆえ,このメソポーラスシリカは新しいマイクロー ナノシステムに応用できる電子デバイス, センサー, ナノ流路, 原子・分子貯蔵容器, 反応チャンバー, さらには分子ふるい 期待される.しかし,これらの研究は著についたばかりで, ア ルコールセンサ8), ポリエチレン細線合成の反応容器) としての 応用研究などがあるが極めて少ない.

このようにメソポーラスシリカは, 特異な幾何学的形状を有 し, 細孔内部表面に特定の有機反応基を修飾 ${ }^{10)}$ できるため新た な物性を付与できる.従って, 新技術を担う材料としての期待 は高い. しかし,この微小構造体を有效利用した工業的プロセ ス化の構築を行うためには, 望みの特定形態に制御することが 重要である. また, 硬さ, 弾性係数や破壊応力などの機械的性 質の解明とそれらの最適化が必要不可欠である.

そこで本研究では, 応用上有用な直線状メソポーラスシリカ を選択的に合成できる条件の解明を第一の目的とした.この検 討には, 本実験では試薬の混合比, 酸性度を変化させた.また, ナノインデンテーション法を用いて硬さ, 弾性係数, 破壊特性 の機械的性質の評価を行い,さらに機械的強度向上のための焼 成条件について検討を行った。

\section{2. 実 験 方 法}

\section{1 形成条件}

本研究では, メソポーラスシリカの形成は既報 ${ }^{11)}$ の水熱 反応によった.この条件では様々な形態の柱状, 粒状構造 体が混在することが知られている. 合成は溶媒に塩酸

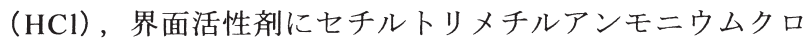
リド $\left(\mathrm{CH}_{3}\left(\mathrm{CH}_{2}\right)_{15} \mathrm{~N}\left(\mathrm{CH}_{3}\right)_{3} \mathrm{Cl}\right.$ : 以下 $\mathrm{C} 16 \mathrm{TMACl}$ と略記), シリ カ源にオルトケイ酸テトラエチル $\left(\left(\mathrm{C}_{2} \mathrm{H}_{5} \mathrm{O}\right)_{4} \mathrm{Si}\right.$ : 以下 TEOS と 略記）を用いた. TEOS は酸性下での加水分解・脱水縮合に よりシリカ $\left(\mathrm{SiO}_{2}\right)$ 非晶質骨格を形成する (図 1 ). 蒸留水 $20 \mathrm{ml}$ で希釈した 5 規定 $(5 \mathrm{~N})$ の $\mathrm{HCl} 70 \mathrm{ml}$ にC16 TMAClを $1.76 \mathrm{~g}$ 加 え, 擋拌後 TEOSを $1.12 \mathrm{ml}$ 添加し, テフロン容器内で $80^{\circ} \mathrm{C}$, 


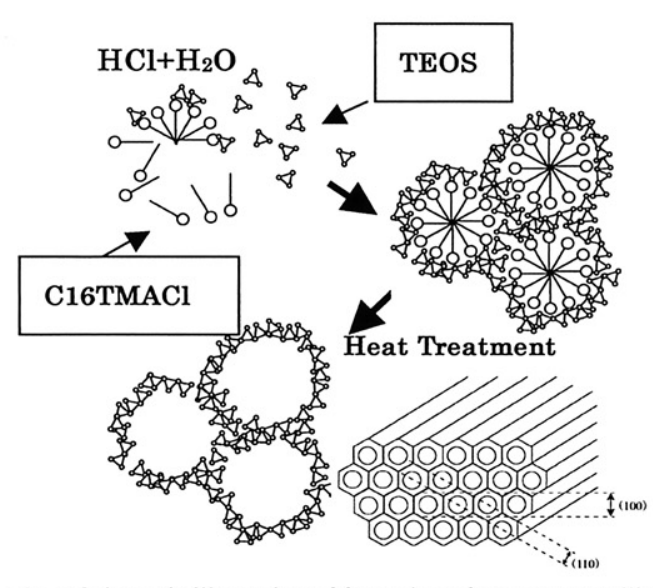

Fig. 1 Schematic illustration of formation of mesoporous silica material

Table 1 Relationship between the synthesis conditions and the sample numbers

\begin{tabular}{c|c|c|c}
\hline \multirow{2}{*}{$\begin{array}{c}\text { 5N HCl(m)- } \\
\mathrm{H}_{2} \mathrm{O}(\mathrm{m})\end{array}$} & \multicolumn{3}{|c}{ C16TMACl(mg)-TEOS(ml) } \\
\cline { 2 - 4 } & Standard & Dilute & Dense \\
\cline { 2 - 4 } & $1.76-1.12$ & $0.44-0.28$ & $7.04-4.48$ \\
\hline $30-60$ & No.2 & No.5 & No.9 \\
\hline $50-40$ & No.3 & No.6 & No.10 \\
\hline $70-20$ & No.1 & No.7 & No.11 \\
\hline $90-0$ & No.4 & No.8 & No.12 \\
\hline
\end{tabular}

168時間静置した.得られた粉末を蒸留水で洗浄処理·室温乾 燥後,電気炉を用いてメソポーラスシリカの焼結および界面 活性剤の除去を行った. 焼成条件は窒素雾囲気中で室温から $550{ }^{\circ} \mathrm{C}$ まで毎分 $10{ }^{\circ} \mathrm{C}$ 上昇させ, $550{ }^{\circ} \mathrm{C}$ で 1 時間保持, さらに 酸素雰囲気で 2 時間保持後室温まで泠却した. 以降, 本条件 を標準条件とする.

形態の制御は標準条件を基準として, $5 \mathrm{~N} \mathrm{HCl}$ と $\mathrm{H}_{2} \mathrm{O}$ の総量 を $90 \mathrm{ml}$ 一定のもと, $\mathrm{HCl}$ 量を $30,50,70,90 \mathrm{ml}$ で変化さ せた. さらにC16TMAClと TEOSの混合比を一定とし, 総量 を標準条件（C16TMACl/TEOS=1.76 g/1.12 ml）の 1/4 倍 (以降低濃度条件と記す), 4 倍 (以降高濃度条件と記す) に 変化させた. 合成条件と対応するサンプル番号を表 1 にまと める.

\section{2 形態および微細組織の锶察}

形態の観察は, 走查型電子顕微鏡 (SEM：日本電子製 JSM6700F) を用いた. 観察は粉末試料をSi ウエハ上に分散させ, 導電性を得るため金コーティングをスパッタリング蒸着法で 行った. また, 微細組織の評価は加速電圧 $300 \mathrm{kV}$ 透過型電 子顕微鏡（TEM：日立製 H-9000UHR）を用いた。この際, $\mathrm{Cu}$ 製メッシュで粉末試料を保持した.

結晶構造の同定には粉末 X 線回折法 (XRD : Philips 製 PW3050)を用いた. 結合状態はフーリエ変換赤外分光法 (FTIR:Perkin Elmer 製 Spectrum 2000）によった.

\section{3 機械的性質の評価}

硬さ, 弾性係数の評価はナノインデンテーション法(CSIRO 製UMIS-2000）を用いた. 圧子には先端曲率約 $100 \mathrm{~nm}$ のダイ ヤモンドのBerkovich圧子を用い, 設定最大荷重值に対して20 ステップ間隔で荷重を制御した.その際の押し込み条件は各

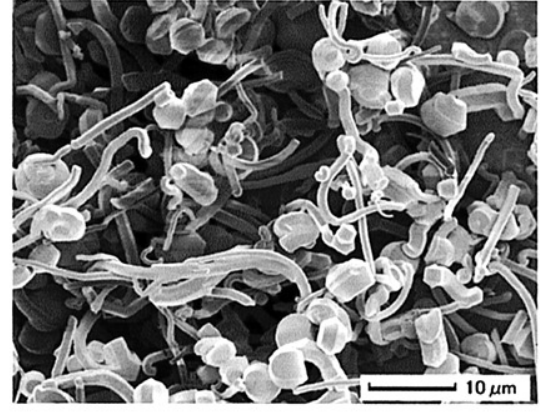

Fig.2 SEM image of mesoporous silica material synthesized at the normal condition ${ }^{11)}$

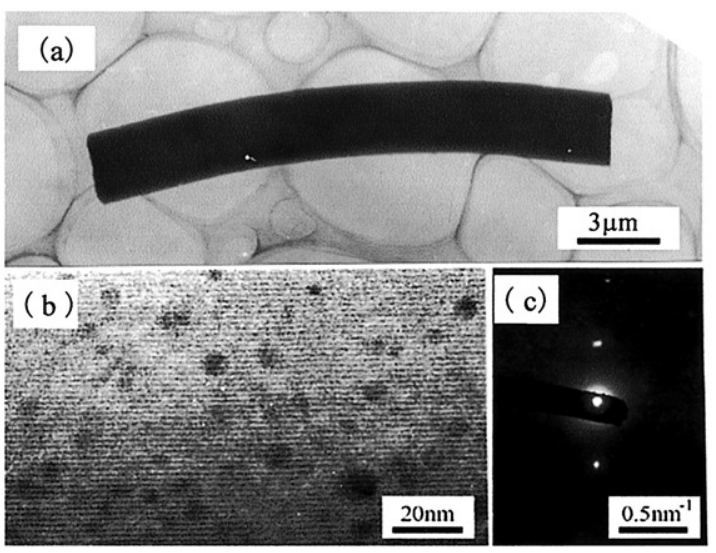

Fig. 3 TEM image of mesoporous silica materials with liear hexagonal rod shape: (a) low magnification image, (b) high magnification image, (c)electron diffraction pattern

ステップについてクリープ等の影響を考虑し,負荷時間と保 持時間はそれぞれ 1.5 秒とした. 約 $100 \mathrm{~nm}$ 以下の浅い押し込 み範囲で定量性を保証するため, 圧子先端の形状補正を弾性 係数既知（ $E=72.5 \mathrm{GPa}, \nu=0.17)$ の溶融石英標準試料を用 いて, 種々の押し込み荷重にて一定の弾性係数が得られるよ うに先端形状を補正した ${ }^{12)}$. また, メソポーラス柱状構造体 の破壊強度特性は, 半径5 $\mu \mathrm{m}$ のサファイ製球圧子を用い, 荷 重一押し込み曲線の不連続点に対応する破壊荷重より評価し た.

\section{3. 実験結果および考察}

\section{1 標準条件での合成}

標準状態で合成された粉末試料のSEM観察結果を図2に示 す. 得られた試料中には, 六角柱構造物, 円柱構造物と粒状 構造物が混在し, 六角柱構造体, 円柱構造体は長さ $10 \sim 20$ $\mu \mathrm{m}$, 直径 $1 \mu \mathrm{m}$ 程度であるが, 長さや直径が大きく異なる直 線状や湾曲状構造体が混在していた.粒状構造体の多くは六 角形を対称軸で回転させた構造を有し直径 $2 \sim 3 \mu \mathrm{m}$ 程度で あった.

細孔径やその周期配列を検討するためXRDおよびTEMによ り微細組織観察を行った. 回折線は $2 \theta=2.3^{\circ}$ （面間隔 $\mathrm{d}=3.8 \mathrm{~nm}), \quad 4.1^{\circ} \quad(\mathrm{d}=2.2 \mathrm{~nm})$ および $4.7^{\circ} \quad(\mathrm{d}=1.9 \mathrm{~nm})$ に観 察された (図17参照).これらの回折線は, (100), (110) お よび (200) 面に対応する ${ }^{11)}$ (図 1 参照).

マイクローナノデバイスに有効な柱状構造体の TEM 観 察像を図3に示す. 観察は低倍率像 (a) に示寸直径 $3 \mu \mathrm{m}$, 長 さ20 $\mu \mathrm{m}$ 程度の六角柱構造体について行った.この構造体の 


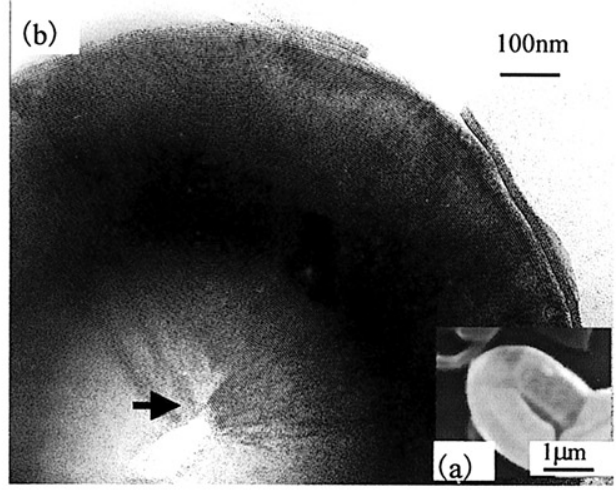

Fig.4 High magnification TEM image of mesoporous silica materials with winding rod shape. The arrow shows the defect of silica wall

高分解能 TEM 観察像を図 (b) に示す．濃いコントラストの 縞状シリカ壁と薄いコントラストの細孔が観察され，そ の配列は約 $2.0 \mathrm{~nm}$ の周期性を有していた。この值はXRD で求めた(110)面の面間距離とほぼ一致している．このこ とはシリカ壁の垂直方向に存在する 2 つ回折スポット （図(c)）からも検証された。ささに他の六角柱構造体の TEM 像では, (100) 面に対応する約 $3.6 \mathrm{~nm}$ の規則構造が観 察された．また，SEM 像図 4 (a)に示す大きく湾曲した六 角柱構造体の TEM 像を図 4 (b) に示す.この構造体の大部 分では, 図 3 (b) 同様のシリカ壁の縞状コントラストで示 される細孔列が約 $3.5 \mathrm{~nm}$ の周期で維持されているが, 湾 曲部の中心部近くでは矢印で示すシリカ壁が途切れた欠 陥が確認された．ナノ流路や電気的配線技術への応用で は，欠陥の存在は悪影響を及ぼす。この観察結果は小さ な曲率半径を持つメソポーラスシリカはデバイス応用に 不適であり，高い直線性を有する構造体の有用性を示す ものである.

さらに, 円柱構造体と粒構造体の内部微細構造の TEM 観察を行った. 円柱構造体の典型例を図 5 に示す. 図 (a) は図 2 のSEM像で見られる円柱構造体の端部で, 図中丸で囲まれ た部分を柱軸と垂直方向に観察した拡大像を(b), 正六角形の 回折スポットが観察されたTED像を (c) に示す. 異なるいずれ の視野でも同様の正六角形状に細孔が整列しているTEM像 (b) および(c)が観察されることから,この構造の細孔配列は,柱 軸と垂直な円断面の半径方向に同心円状に配列していること がわかる.この微細構造は柱軸方向と平行に細孔構造を有す る六角柱構造体 (図 3 (b)) とは異なる. 回転体の円形断面を 有する粒構造体においても, 図 5 と同様のTEM観察結果であ ることから，(d)に示すように細孔がリング状で結合された内 部構造であることが推測される.従って, 円柱構造体は粒状 構造体が回転対称軸方向に長く成長した形態であると判断さ れた.

以上, 標準条件での合成では, それぞれ同一の細孔の周期 性を有するが, 外形寸法の異なる六角柱構造, 円柱構造と粒 構造の 3 種類の形態を有する構造体が形成された.

\section{2 形態の制御}

マイクローナノデバイス応用に有効な直線性の高い六 角柱構造体を，選択的に形成可能な条件を検討した。界 面活性剂・シリカ源量の標準条件, 低濃度条件および高濃度 条件に対して，それぞれ $\mathrm{HCl}$ 量を $30,50,70,90 \mathrm{ml}$ と変化 させた場合に形成される構造体の変化をSEM観察より検討し

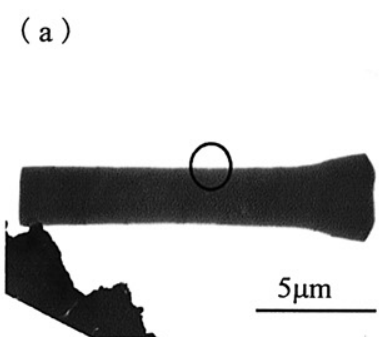

(b)

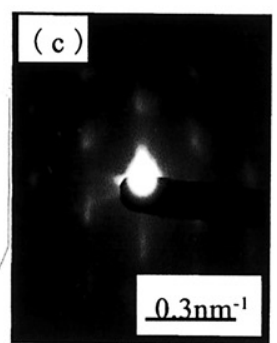

(d)
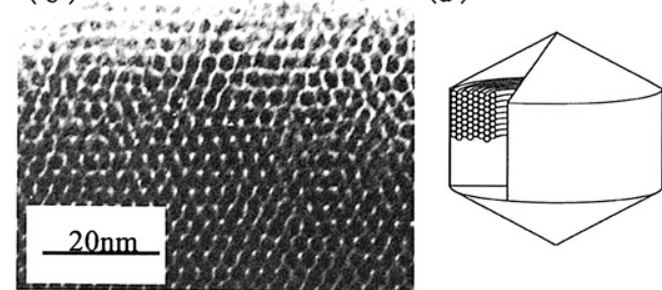

Fig.5 TEM image of mesoporous silica materials with columnar shape: (a) low magnification image,(b) high magnification image,(c)electron diffraction pattern, (d) Schematic illustration of a microstructure model

た. なお, XRDおよびTEMによる微細構造評価結果は標準条 件と同一であり,以下省略する.

\section{2 .1 標準条件での塩酸濃度依存性}

$\mathrm{TEOS}$ と $\mathrm{C} 16 \mathrm{TMACl}$ 濃度を標準条件として, $\mathrm{HCl}$ 量を変 化させた場合の観察結果を図 $6 \sim 8$ に示す. $\mathrm{HCl}$ 量 $30 \mathrm{ml}$ の No. 2 (図6)では, ほぼすべてが直径5～10 $\mu \mathrm{m}$ の粒構造であっ た. $\mathrm{HCl}$ 量 $50 \mathrm{ml}$ の No. 3(図 7) では, 粒構造と円柱構造が主 体的であるが, わずかに六角柱構造体の形成が確認される. $\mathrm{HCl}$ 量 $90 \mathrm{ml}$ の No. 4 (図8) では粒構造の割合が減少し, 直径 $1 \mu \mathrm{m}$ 程度の六角柱構造体が多く形成された. しかしながら， 標準条件試料No. 1 (図2) と比較すると, 湾曲など乱雑さの 増加が観察されたが, $\mathrm{HCl}$ 濃度の増加により粒構造から六角 柱構造体に変化する定性的傾向が確認された.

\section{2 .2 低濃度条件での塩酸濃度依存性}

TE0S，C16TMAC1 濃度を標準条件の $1 / 4$ とした低濃度条 件での SEM 観察結果を図 $9 \sim 12$ に示す. HC1 量 $30 \mathrm{ml}$ の No. 5 (図 9) では直径 $3 \mu \mathrm{m}$ 程度の粒構造と直径数百 $\mathrm{nm}$ の 縮れた六角柱構造体が主であり, 種々の直径, 長さの円 柱構造体が混在していた. $\mathrm{HCl}$ 量 $50 \mathrm{ml}$ の No. 6 (図 10) で は直径 $3 \mu \mathrm{m}$ 前後の粒構造体が主に観察された. わずかで はあるが六角柱構造体や円柱構造体が形成された． $\mathrm{HCl}$ 量 $70 \mathrm{ml}$ の No. 7 (図 11) まで $\mathrm{HCl}$ 濃度を増加させた場合, 直 径約 $1 \mu \mathrm{m}$, 長さ数〜数十 $\mu \mathrm{m}$ の六角柱構造体と粒構造体 の混合状態となった. 同 HC1 濃度である標準状態 (No. 1) と比較すると粒状と六角柱構造体の混合割合に大きな変 化は見られないが, 六角柱構造体は短く, 直線性の低下 が見られ，乱雑さが大きくなっている．さらに $\mathrm{HCl}$ 濃度 を増加させた $\mathrm{HCl}$ 量 $90 \mathrm{ml}$ の No. 8 (図 12) では粒構造体の 割合の低下が見られるが，大きく湾曲している構造体が 多く, 形態の統一性がさらに低下した。

\section{2 .3 高濃度条件での塩酸濃度依存性}

TEOS, C16TMACl 濃度を標準条件の 4 倍とした高濃度 条件での SEM 観察結果を図 $13 \sim 16$ に示す. $\mathrm{HCl}$ 量 $30 \mathrm{ml}$ の No. 9 (図 13)および. HCl 量 $50 \mathrm{ml}$ の No. 10 (図 14) は粒構造体 が支配的であった.C16TMACl·TEOS量を低濃度条件から標 準条件にすることで形態寸法変化は小さかったが, 高濃度条 


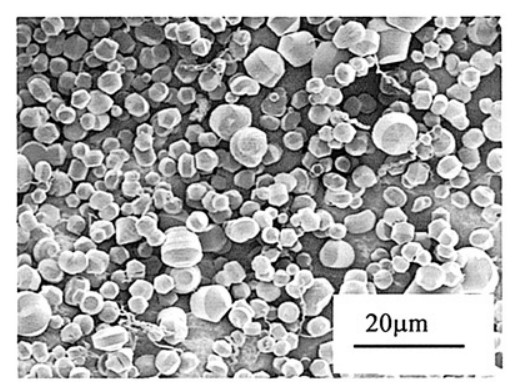

Fig.6 SEM image of mesoporous silica sythesized at the experimental condition of No.2

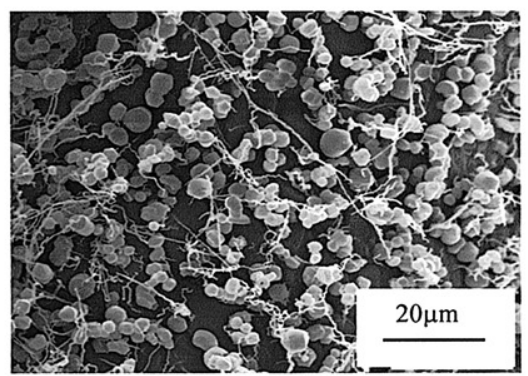

Fig.9 SEM image of mesoporous silica synthesized at the experimental condition of No.5

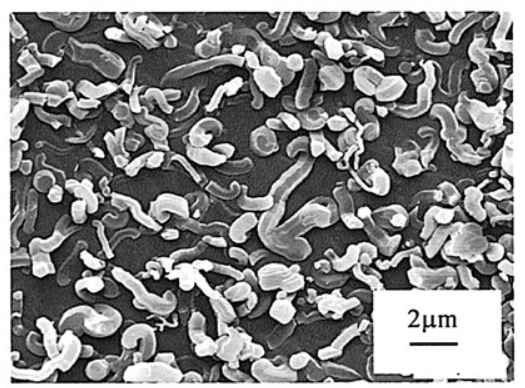

Fig.12 SEM image of mesoporous silica synthesized at the experimental condition of No.8

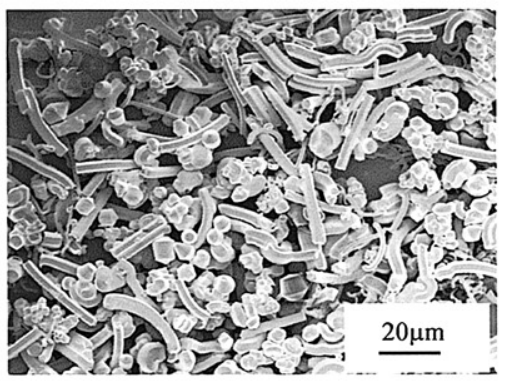

Fig.15 SEM image of mesoporous silica synthesized at the experimental condition of No.11

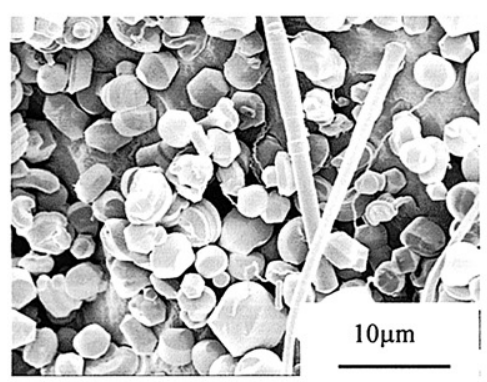

Fig.7 SEM image of mesoporous silica synthesized at the experimental condition of No.3

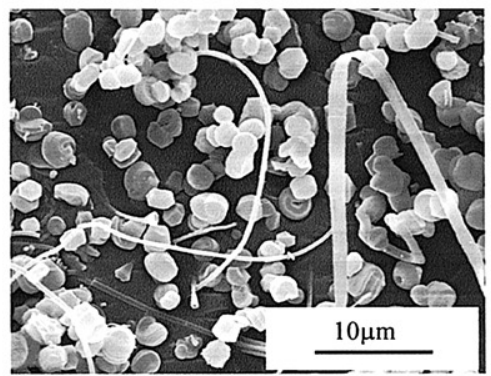

Fig.10 SEM image of mesoporous silica synthesized at the experimental condition of No.6

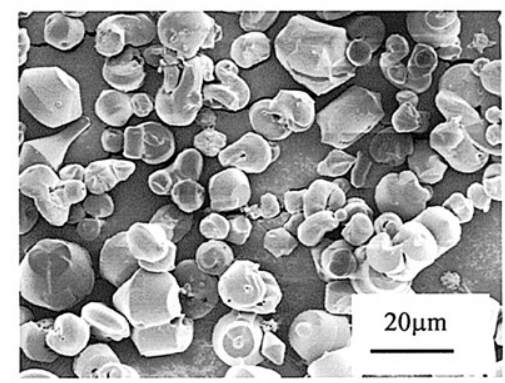

Fig.13 SEM image of mesoporous silica synthesized at the experimental condition of No.9

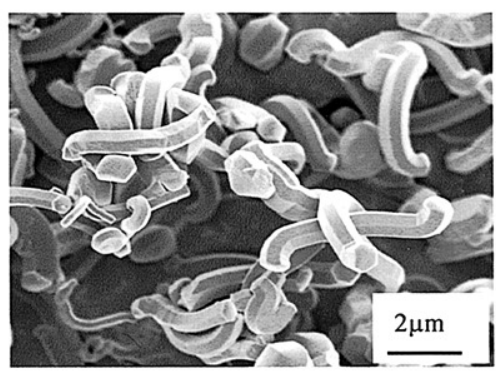

Fig.8 SEM image of mesoporous silica synthesized at the experimental condition of No.4

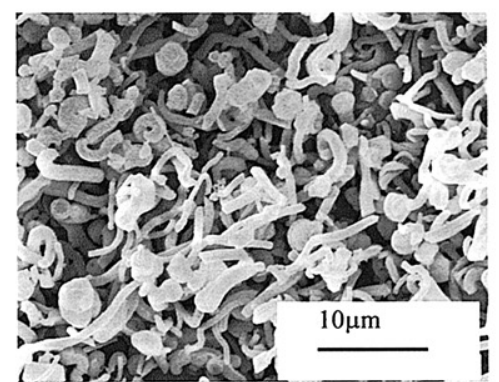

Fig.11 SEM image of mesoporous silica synthesized at the experimental condition of No.7

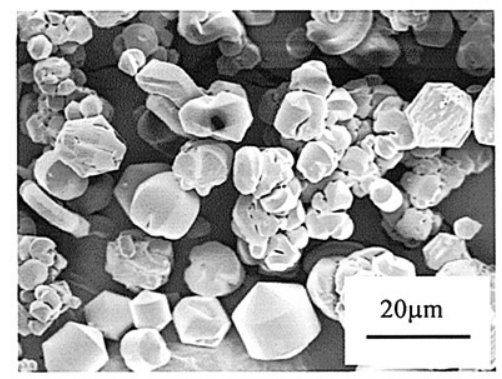

Fig.14 SEM image of mesoporous silica synthesized at the experimental condition of No.10

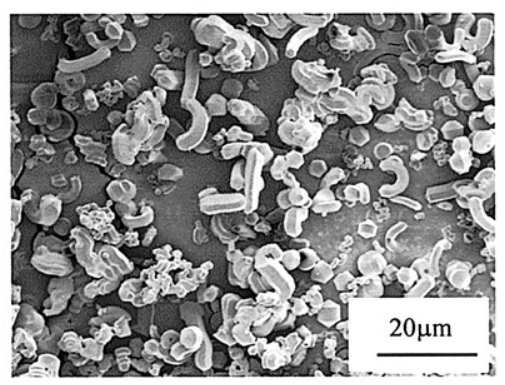

Fig.16 SEM image of mesoporous silica synthesized at the experimental condition of No.12
件では粒構造の直径 $10 \sim 20 \mu \mathrm{m}$ と著しく成長した. $\mathrm{HCl}$ 量 $70 \mathrm{ml}$ の No. 11 (図 15) では図 3 に示したような直線性の 高い六角柱構造体が支配的であった。 その直径 $5 \sim 10$ $\mu \mathrm{m}$, 長さ数 $10 \sim 50 \mu \mathrm{m}$ と大きく成長した構造体を形成で きた。しかし，さらに $\mathrm{HCl}$ 量増加させた $90 \mathrm{ml}$ の No. 12 (図 16)では, 微細化した構造体が混在した形態に急激に変化 した.この原因については不明であり今後検討する．以 上の結果, 直線性の高い六角柱構造体の最適形成条件は, 高嶩度条件下の $\mathrm{HCl}$ 量 $70 \mathrm{ml}$ （図 15）であることが分った.
以上の合成条件と形態の変化について表 2 にまとめる.

3.2 .4 合成条件が形態に与える影響の考察

C16TMACl ・ TEOS 量は構造体の寸法に, $\mathrm{HCl}$ 濃度は形態 に大きく影響した，界面活性剤の濃度によりミセルの集 合サイズが大きくなるため, それを鋳型としたメソポー ラスシリカ構造体の寸法も大きくなったものと考えられ る. No.11 (図 15) のように六角柱構造体では直径が太く なることで, ミセルの自由度が低下し, より安定した直 線的な構造に変化するものと考察される. 
Table 2 Morphology of mesoposrous silica material synthesized at various reaction conditions. $\mathrm{G}, \mathrm{C}$ and $\mathrm{H}$ mean grain shape columnar shape and hexagonal rod shape, respectively.

Parentheses indicate the small fraction

\begin{tabular}{c|c|c|c}
\hline \multirow{2}{*}{$\begin{array}{c}5 \mathrm{~N} \mathrm{HCl}(\mathrm{ml})- \\
\mathrm{H}_{2} \mathrm{O}(\mathrm{ml})\end{array}$} & \multicolumn{3}{|c}{ C16TMACl(mg)-TEOS(ml) } \\
\cline { 2 - 4 } & Standard & Dilute & Dense \\
\cline { 2 - 4 } & $1.76-1.12$ & $0.44-0.28$ & $7.04-4.48$ \\
\hline $30-60$ & $\mathrm{G}$ & $\mathrm{G}+(\mathrm{H})$ & $\mathrm{G}$ \\
\hline $50-40$ & $\mathrm{G}+(\mathrm{C})$ & $\mathrm{G}$ & $\mathrm{G}$ \\
\hline $70-20$ & $\mathrm{G}+\mathrm{C}+\mathrm{H}$ & $\mathrm{G}+\mathrm{H}$ & Linear-H \\
\hline $90-0$ & Winding-H & $\mathrm{H}+(\mathrm{G})$ & $\mathrm{H}+\mathrm{G}$ \\
\hline
\end{tabular}

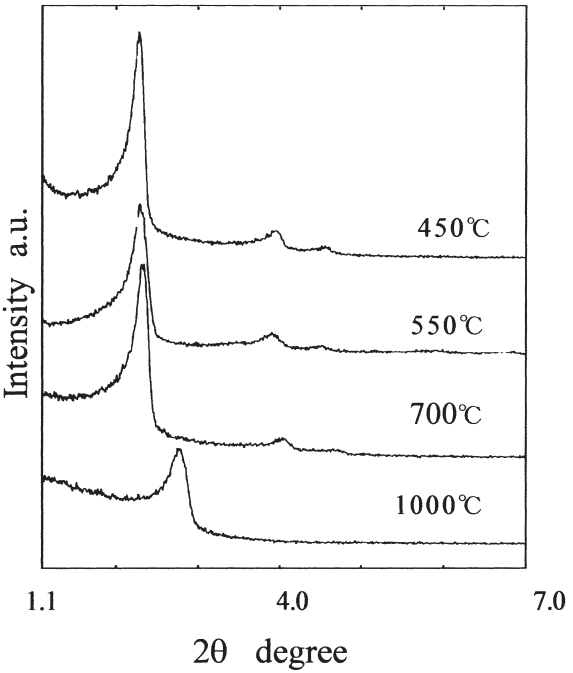

Fig.17 Typical XRD pattern of mesoporous silica material synthesized at the various calcination temperature

$\mathrm{HCl}$ 濃度はミセルの形態と，TEOS の結合に大きな影響 を与えた. HCl 濃度が低い状態では TEOS の結合が弱く， シリカ壁の結合スピードが遅いため, ミセルは比較的自 由な形態を取ることが可能である．従って，表面エネル ギがより低い状態，すなわち粒構造を形成すると考えら れる。このため, 標準条件よりも高 $\mathrm{HCl}$ 濃度では六角柱 構造の形成割合が高くなったと考察される．更なる形態 制御は，酸の種類や C16TMACl・TEOS 比を変化させるな ど今後の課題である.

\section{3 機棫的性質の評価と焼成条件の最適化}

標準条件（No.1）にて合成を行った六角柱構造体に対 して, 従来条件の $550{ }^{\circ} \mathrm{C}$ さらに $450,700,1000{ }^{\circ} \mathrm{C}$ の温度 で焼成した.XRD, FT-IRによる微細構造の変化について検討 した.また, シリカ壁の柱軸方向に対して垂直方向の硬さと 弾性係数, および構造体の破壊特性をナノインデンテーショ ン法を用いて測定し, 焼成温度の最適条件を明らかにした。

\section{3 .1 微細構造の評価}

焼成後の微細構造をXRDによって測定した.測定結果を図 17 に示す. $450{ }^{\circ} \mathrm{C}$ で焼成した試料は $5500^{\circ} \mathrm{C}$ と同様の回折ピー

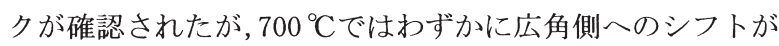
見られた. $1000{ }^{\circ} \mathrm{C}$ では (100) 面の回折ピークは $2 \theta=2.8^{\circ}$ $(\mathrm{d}=3.2 \mathrm{~nm})$ と大きく広角に移動し, ピーク強度も低下した. また, (110)面および(200)面に対応するピークは消失した.こ れは高温の焼成によってシリカ壁が収縮し, 細孔の規則性が

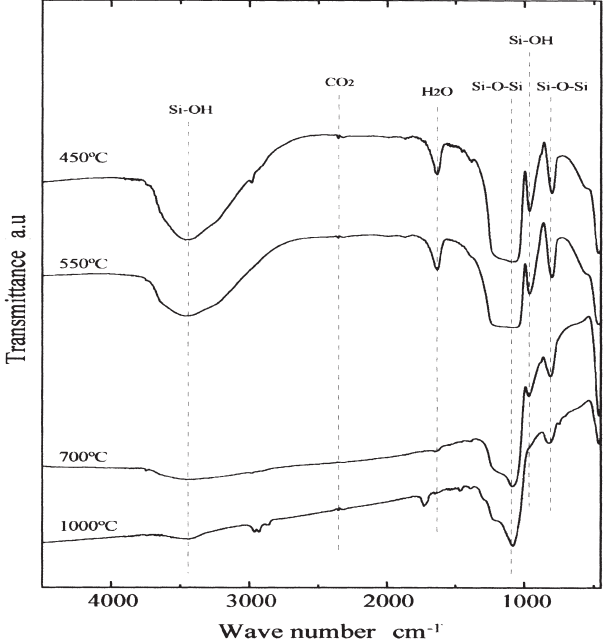

Fig.18 Fourier-transform infrared spectroscopy of mesoporous silica material synthesized at the various calcination temperature

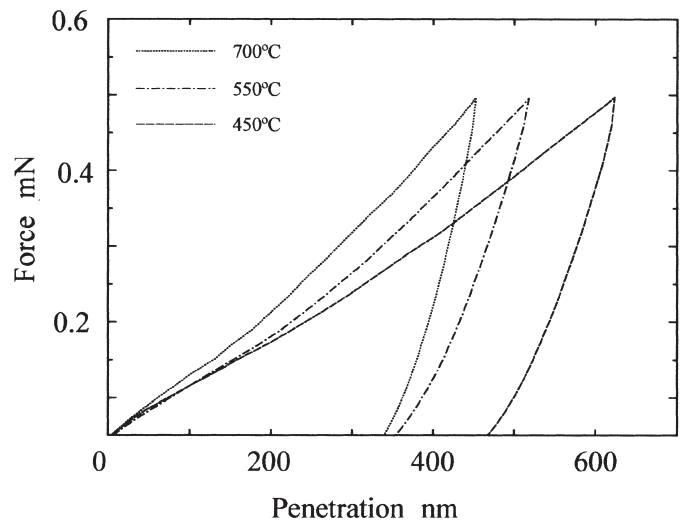

Fig.19 Typical penetration-force curves in nano-indentation experiments for mesoporous silica material synthesized at the various calcination temperature

著しく低下したものと判断される.

結合状態をFT-IRによって測定した. 図 18 に測定結果 を示す，焼結温度の上昇によって $\mathrm{Si}-\mathrm{OH}\left(3400 \mathrm{~cm}^{-1}, 930\right.$ $\left.\mathrm{c} \mathrm{m}^{-1}\right)$ に起因する吸収ピークが減少し, $\mathrm{SiO}_{2}$ のピーク $\left(1070 \mathrm{~cm}^{-1}, 800 \mathrm{~cm}^{-1}\right)$ 強度の増加傾向が観察された。こ れは高温での焼成によって, $\mathrm{Si}-\mathrm{OH}$ が脱水縮合し $\mathrm{SiO}_{2}$ に 変化したと考えられる。

以下の機械的性質の評価では, XRDで細孔の収縮と規則性 の低下および表面に割れが観測された $1000{ }^{\circ} \mathrm{C}$ で焼成した構 造体は除外した。

\section{3 .2 硬さおよび弾性係数测定}

六角柱構造体側面のメソポーラスシリカ壁の硬さ, 弾 性係数をナノインデンテーション法により評価した. 構造体 はSiウエハー上にアセトンで分散・乾燥させ表面力のみで固 定した. 装置に付属する光学顕微鏡で独立した六角柱構造体 を確認後, 測定を行った. 測定時の室温は $20 \pm 1{ }^{\circ} \mathrm{C}$, 相対 湿度 $35 \%$ であった。

測定された押し込み荷重と深さの関係を図19に示す.最大 荷重0.5 mNに対して, 焼成温度上昇に伴い押し込み深さの 減少, および除荷時の初期勾配が急峻になっていることが確 認される.これらは, 焼成温度の上昇に伴う硬さ, 弾性係数 
Table 3 Hardness, Youg's moduli and fracture loads of mesoporous silica material synthesized at the various calcination temperature

\begin{tabular}{c|c|c|c}
\hline $\begin{array}{c}\text { Calcination } \\
\text { temparature }\left({ }^{\circ} \mathrm{C}\right)\end{array}$ & $\begin{array}{c}\text { Hardness } \\
(\mathrm{MPa})\end{array}$ & $\begin{array}{c}\text { Young's } \\
\text { modulus(GPa) }\end{array}$ & $\begin{array}{c}\text { Fracture } \\
\text { load(mN) }\end{array}$ \\
\hline 450 & 30 & 0.9 & 0.1 \\
\hline 550 & 50 & 1.1 & 0.2 \\
\hline 700 & 60 & 1.6 & 0.25 \\
\hline
\end{tabular}

の増加を定性的に示すものである. 算出された硬さ, 複 合弾性係数を表 3 に示す. 定量的にも焼成温度の上昇に 伴う機械的性質の向上が確認された。これは前述の $\mathrm{SiO}_{2}$ 結合の促進によるものと判断される。しかし，これらの 值は同一材料の $\mathrm{SiO}_{2}$ で構成される溶融石英標準試料の測 定值, 硬さ $11 \mathrm{GPa}$ および弾性係数の測定值 $72.5 \mathrm{GPa}$ と比 較すると格段に小さい. これは細孔の存在によるためと 考えられる.

\section{3 .3 破壊荷重の測定}

直径 $5 \mu \mathrm{m}$ の球圧子を用いて六角柱構造体全体の破壊荷重 を測定した.荷重一押し込み曲線の測定結果の一例を図20に 示寸.破壊は押し込み量が急激に変化している点(図中矢印) で発生するものと考えられ, それぞれの破壊荷重を表3に同 時に示す. 同様に焼結温度の上昇に伴う $\mathrm{SiO}_{2}$ 結合の促進によ り破壊荷重も増加することが分かった。

以上より, 焼成温度の上昇により機械的特性の向上が見ら れたが, $1000{ }^{\circ} \mathrm{C} て ゙$ 規則性の低下が起こることが分かった. よって最適焼結温度は約 $700{ }^{\circ} \mathrm{C}$ と決定できた。

\section{4. 結}

ナノスケールの周期配列した細孔を有するメソポーラ スシリカはマイクローナノデバイスへ応用可能な新規材 料である. 本研究では, 応用上有効な直線性を有する六 角柱状構造体の形態制御に注目し, 試薬の混合比, 酸性 度を変化させ検討を行った。 また, 六角柱構造体の硬さ, 弾性係数, 破壊荷重の機械的性質の評価を行い, さらに 機械的強度向上のための焼成条件について検討を行っ た。以下に結論を示す。

(1) $\mathrm{HCl}$ 濃度, C16TMACl・TEOS 量を変化させることで 形態は大きく変化したが, 内部の周期的微細構造に は変化はなかった。 $\mathrm{HCl}$ 濃度は形態に大きく影響し, 低 $\mathrm{HCl}$ 濃度では粒状構造, 高 $\mathrm{HCl}$ 濃度では六角柱構 造が形成された。一方, C16TMACl・TEOS 量は形態 の寸法に影響し, 濃度上昇に伴い寸法の大きい構造 体を得ることが出来た。

（2）直線性の高い六角柱構造体の形成条件は, $5 \mathrm{~N} \mathrm{HCl}-$ $\mathrm{H}_{2} \mathrm{O}$ 量を $70 \mathrm{ml}-20 \mathrm{ml}$ に, C16TMACl・TEOS 量を 1.76 $\mathrm{g} \cdot 1.12 \mathrm{~m} 1$ の 4 倍であった.

（3）ナノインデンテーション法により, 焼成温度に対 する六角柱構造体のシリカ壁面の硬さ, 弾性係数お

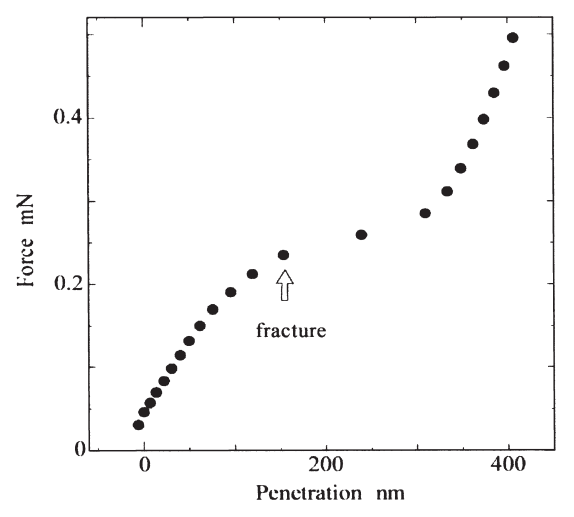

Fig.20 Typical penetration-force curves in the case of occurence of fracture at nano-indentation experiments for mesoporous silica material synthesized at the s calcination temperature of $550^{\circ} \mathrm{C}$

よび構造体全体の破壊荷重を決定した。焼成温度の 上昇に伴い機械的特性は向上したが， $1000{ }^{\circ} \mathrm{C} て ゙$ 規則 性の低下が起こることが分かった。 よって, 最適焼結 温度は約 $700{ }^{\circ} \mathrm{C}$ であった。

以上, メソポーラスシリカは直線状六角柱構造体の形 態制御が可能で, 焼成条件の変化により最適化された機 械的性質を有することが分かった，従って，マイクロ・ ナノパーツへの応用の可能性を明らかにすることができ た.

\section{謝辞}

メソポーラスシリカ合成に関して多大なるご指導をい ただきました産業技術総合研究所木村辰雄博士に心より 感謝します. また, ナノインデンテーション試験では, 装 置を供与していただきました愛知県工業技術センター菅 沼幹裕博士に御礼申し上げます。

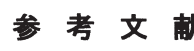

1) S. Matsui and Y. Ochiai, Nanotechonolgy, 7(1996)247.

2) D.M.Eigler and E.K.Schweizer Nature, 344 (1990)524.

3) R.D.Richard, J.Zhu, F. Xu, S.Hong and C. A. Mirkin, Science, 283(1999)661.

4) H.Masuda, H.Yamada, M. Satoh and H. Asoh, Appl.Phys.Lett., 71(1997)2770.

5) L. M. Adleman, Am. Math. Soc, 27 (1995)1.

6) T.Yanagisawa, T. Shimuzu, K. Kuroda and C. Kato, Bull.Chem.Soc.Jpn., 63 (1990)988.

7) T.Yanagisawa, T. Shimizu, K. Kuroda and C. Kato Bull.Chem.Soc.Jpn., $63(1990) 1535$.

8) P.Innocenzi, A. Martucci, M. Guglielmi, A. Bearzotti, E. Traversa and J.C. Pivin, J.Euro.Cer.Soc., 21 (2001)1985.

9) K.Kageyama, J. Tamazawa and T. Aida, Science, 285 (1999) 2113

10)X.Feng, G. H. Fryxell, L.-Q. Wang, A. Y. Kim, J. Liu and K. M. Kemner, Science, 276 (1997)923.

11) H.Yang, A. Kuperman, N. Coombs, S. M. Afara and G. A. Ozin, Nature, 379 (1996)703.

12)A. Matsumuro, T. Watanabe, T. Hayashi, T. Mori and Y.Takahashi, Mater. Sci. Res. Inter. 6 (2000)180. 